\title{
THE POLICY OF GRANTING COMPENSATION AND APPARATUS PERFORMANCE IMPROVEMENT
}

\author{
Suharto ${ }^{1}$ \\ Suwignyo Widagdo ${ }^{2}$ \\ Yuniorita Indah Handayani ${ }^{3}$ \\ Higher Education of Economic Mandala \\ e-mail: suharto290166@gmail.com
}

\begin{abstract}
This study aims to determine the effect of compensation on employee performance, either partially or simultaneously. This research was conducted at Environment Agency of Bondowoso Regency with total sample of 100 employees. The analysis tool used is multiple linear regression with $t$ test analysis tools and $F$ test. The analysis process using SPSS statistical software. Hypothesis test results show that compensation consisting of basic salary, commission, incentive, structural allowance, overtime pay, social security, recognition and responsibility both partially and simultaneously affect the performance of employees. The contribution of variable compensation to employee performance is very dominant as evidenced by the coefficient of determinant $0.98 \%$.
\end{abstract}

Keywords: Motivation, Compensation, Performance

\section{INTRODUCTION}

The phenomenon of low performance of Civil State Apparatus (ASN) is obviously seen today. This shows that the commitment of the Apparatus to the organization, especially on responsibility, is not in accordance with what is expected by the organization. It possibly started from the material and nonmaterial compensation facilities that have not been in accordance with their expectations. As an organizational asset, personnel and as human resources, they have an important role for achieving organizational goals. This means that the aspects of compensation as well as incentives as an improvement of selfquality and commitment to the organization need to be improved. Compensation improvements can be achieved through enhancement, selfquality through training programs and commitment to the organization through the intensity of coaching advancement within the organization.

Management of compensation and incentives is crucial to its function within the organization. It is usually a part and responsibility of the Chairman of the Organization. One of the most important phases of employment on the sight of most apparatus is the level of compensation and incentives that suit their needs. In general, incentives and compensations are provided equivalent to qualifications that relevant to the work and the number of persons in the qualified workforce. The granting of overtime pay or compensation and incentives are also determined by the skills and efforts required to fulfill a job and the level of competence of the work assessed by the organization and society (Simamora, 2007: 539)

In modern organizations, with a wide range of expensive employee benefit programs, salary incentive programs and structured pay scales, compensation assignments are even more difficult and 
challenging for human resources specialists. Employee compensation and incentives will affect their performance tendency to stay with the organization or look for other jobs. Despite of disagreement of the leaders on the extent to which forms of compensation and incentives can affect employee performance and productivity, it is undeniable that the appropriate compensation position and incentive form is essential to be taken.

In addition through the development of appropriate compensation needs for employee performance improvement efforts, it is also needed to be supported by the leadership style which is responsive and loyal to employees. The existence of a responsive and loyal leadership toward employees is seen as one of the key implementation of the implementation of the type of compensation in improving employee performance. Therefore, efforts to improve the performance of employees through appropriate types of compensation and supported the existence of a responsive and loyal leadership of motivation and leadership toward employees will be able to achieve the goal of mutual objectives.

The purpose of this study is to examine the effect of compensation variable (basic salary, commission, incentive, structural allowance and overtime pay, social security, health assurance, acknowledgment and responsibility) either partially or simultaneously to State Civil Apparatus performance at Environment Agency of Bondowoso Regency.

\section{RESEARCH METHODS}

This research was conducted at Environmental Agency of Bondowoso. The samples of this research were 100 respondents from 183 population determined using Singarimbun and Sofyan criteria. (2009: 98). Sampling is not less than $10 \%$ and not more than $55 \%$ of the total population of the population, so to determine the size of the sample in this study is in accordance with the opinion set at $54.64 \%$ of the population. While this type of research is descriptive quantitative. Data were collected through questionnaires and interviews.

There are two variables of this research namely independent variable (X) and dependent variable (Y). Independent variables consist of Basic Salary (x1), Commission (x2), Incentive (x3), Structural Allowance (x4), Overtime pay (x5), Social Security (x6), Recognition (x7), and Responsibility (x8) ). While the dependent or dependent variable is the performance variable ASN (Y)

Operational definition of each variable is described as follows:

1. The performance of the State Civil Apparatus is the work achieved by a State Civil Officer in performing the duties and responsibilities imposed on him, as measured by a questionnaire determining the following facts:
a. Work quality factor
b. Work quantity factor
c. Reliability factor
d. Attendance factor
e. Cooperation factors

2. Compensation in the form of:

a. Salary; is a money-in-kind income received by an employee in each month on the basis of the applicable

Government Regulations and is paid in stages.

b. Commission; is the compensation given by the leadership or direct superior to the staff / employee whose nominal amount depends on the leader's consideration. In general, the comisssion is given by the direct supervisor at a certain time and assessed by the boss at that time also.

c. Incentives; are an appreciation in the form of money given by the 
leaders of the organization to employees so that they work with high motivation and pursue for achievement in achieving organizational goals.

d. A structural allowance; is a form of allowance granted to an employee on the basis of a structural position held by an employee, such as a head of department or other allowance.

e. Overtime pay; is a reward or income given to an employee based on a specified period of time, determined on a time basis. Like per hour, per day, per week, per month.

f. Social Security; is a form of guarantees provided by the institution or organization to employees outside of salary. Social benefits include family benefits (children \& wives), and also health.

g. Recognition; is an appreciation given for achievements or existence of an employee. Appreciation of recognition must be given precisely to be associated with real achievement.

h. Responsibility; is the granting of authority to run a type of work or task. A person can be motivated by given greater responsibility for his work. This is a very essential process of empowerment. The giving of responsibilities is in line with the concept of intrinsic motivation based on the content of office.

The research instrument was tested by testing the validity and reliability of statement items using a scale of 1-3.

a. Test Data Normality

The data normality test was performed by using One $\neg$-Sample Kolmogorov Smirnov test. A data distribution is valid if the value shows $p>$ : 0.05 . b. Multicolinearity Test

The multicollinearity test is performed to see whether there is a strong (collinier) relationship between the variables $X$. If there is a strong relationship, then one of the $\mathrm{X}$ variables should be discarded. The boundary of a relationship is said to be strong is if the correlation between $\mathrm{X}$ that occurs has a value of $r>0.8$ (Hadi, 1998).

c. Heterocedasticity Test

Testing of heterocedasticity done by using Spearman correlation. A regression model is said to not occur heterocedasticity if variable of research variable has no correlation with residue $(\mathrm{p}>0,05)$.

\section{RESULT ANALYSIS}

As stated in the hypothesis formulated in this study, to examine how far the influence of the type of compensation type on the performance of Apparatus in Environment Agency of Bondowoso is done by multiple regression analysis approach, as follows:

$\mathrm{Y}=\mathrm{a}+\mathrm{b} 1 \mathrm{X} 1+\mathrm{b} 2 \mathrm{X} 2+\mathrm{b} 3 \mathrm{X} 3+\mathrm{b} 4 \mathrm{X} 4+$ $\mathrm{b} 5 \mathrm{X} 5+\mathrm{b} 6 \mathrm{x} 6+\mathrm{b} 7 \mathrm{X} 7+\mathrm{b} 8 \mathrm{X} 8+\Sigma$

$\mathrm{Y}=$ Performance of Civil State Apparatus

$\mathrm{X} 1=$ Basic Salary

$\mathrm{X} 2=$ Kornisi

$\mathrm{X} 3=$ Incentives

$\mathrm{X} 4=$ Structural Benefits

$\mathrm{X} 5=$ Overtime pay

$\mathrm{X} 6=$ Social Security

X7 = Recognition

$\mathrm{X} 8=$ Responsibility

$\Sigma=$ Interrupt variable

\section{Hypothesis Testing Research}

The largest coefficient is the value of $s \beta=0.05$. While to test the third hypothesis, namely the contribution of dominant variable of the type of compensation, was applied by finding the value of $\alpha=0.05$. To test the second hypothesis, namely the influence of types of compensation partially on employee 
performance is done by statistical test $\mathrm{t}$, at $\alpha$. To test the first hypothesis, i.e. the effect of compensation simultaneously on employee performance is done by statistical test $F$, at $\alpha<0,05$. To test the second hypothesis, namely the influence of types of compensation partially on employee performance is done by statistical test $t$, at $\alpha$. While to test the third hypothesis, namely the contribution of dominant variable of the type of compensation, done by finding the value of the largest coefficient of standarized. The result of regression equation is obtained as follows:

Table 1. Regression Test Results

Coefficients $^{\mathrm{a}}$

\begin{tabular}{|c|c|c|c|c|c|c|c|c|c|}
\hline \multirow[b]{2}{*}{ Mode } & & \multicolumn{2}{|c|}{$\begin{array}{c}\text { Unstandardized } \\
\text { Coef ficients }\end{array}$} & \multirow{2}{*}{$\begin{array}{c}\text { Standardized } \\
\text { Coef ficients } \\
\text { Beta }\end{array}$} & \multirow[b]{2}{*}{$t$} & \multirow[b]{2}{*}{ Sig. } & \multicolumn{3}{|c|}{ Correlations } \\
\hline & & B & Std. Error & & & & Zero-order & Partial & Part \\
\hline \multirow[t]{9}{*}{1} & (Constant) & $7,930 \mathrm{E}-02$ & 1,674 & &, 047 &, 962 & & & \\
\hline & Gaji & 2,057 & ,136 &, 516 & 15,095 & ,000 & ,941 & 845 & 214 \\
\hline & Komisi & 1,663 & ,146 & ,394 & 11,427 &, 000 & 919 & ,768 & 162 \\
\hline & Insentif &,- 869 & 163 &,- 224 & $-5,322$ &, 000 &, 618 &,- 487 &,- 075 \\
\hline & Tunjangan Struktural &, 369 & 187 &, 096 & 1,973 &, 052 &, 843 & 203 & 028 \\
\hline & Bayaran &, 581 & 142 & ,127 & 4,104 &, 000 & ,796 & ,395 & 058 \\
\hline & Jaminan Sosial & 228 & 149 & ,053 & 1,531 & , 129 & ,622 & , 159 & ,022 \\
\hline & Pengakuan & ,291 & 111 & ,078 & 2,614 & ,010 &, 812 & ,264 & ,037 \\
\hline & Tanggung jawab & $-2,428 \mathrm{E}-02$ & ,187 &,- 006 &,- 130 & ,897 & ,921 &,- 014 &,- 002 \\
\hline
\end{tabular}

a. Dependent Variable: Kinerja

Explanation of Equation Result the above regression is as follows:

$\mathrm{Y}=7,930+2,057 \times 1+1,663 \times 2-$

$0,869 \times 3+0,369 \times 4+0,581 \times 5+0,228 \times 6+0,29$ $1 \times 7-2,428 \times 8$

Results of Hypothesis Testing Research

Table 2. Statistical Test Results F

ANOVA $^{\mathrm{b}}$

\begin{tabular}{|ll|r|r|r|r|r|}
\hline \multicolumn{1}{|c|}{} & \multicolumn{1}{|c|}{$\begin{array}{c}\text { Sum of } \\
\text { Model }\end{array}$} & Squares & \multicolumn{1}{c|}{ df } & Mean Square & \multicolumn{1}{c|}{$\mathrm{F}$} & Sig. \\
\hline 1 & Regression & 41707,630 & 8 & 5213,454 & 610,994 &, $000^{\mathrm{a}}$ \\
& Residual & 776,480 & 91 & 8,533 & & \\
& Total & 42484,110 & 99 & & & \\
\hline
\end{tabular}

a. Predictors: (Constant), Tanggung jawab, Jaminan Sosial, Bay aran, Pengakuan, Komisi, Gaji, Insentif, Tunjangan Struktural

b. Dependent Variable: Kinerja

Testing of the first hypothesis, done with statistics F. Based on regression results in regression processed appendix, obtained statistical price $\mathrm{F}=610,994)$ with $\mathrm{p}=$ 0.000 . Because the value of $p<0,05$, hence the hypothesis can be accepted, so that all kind of compensation type together have an effect on to performance of State Civil Apparatus in Environmental Agency of Bondowoso Regency. 
2. Test results of the second hypothesis results $\mathrm{t}$ are as follows: using $t$ statistics. Based on statistical

Table 3. Statistical Test Results t

Coefficients $^{\mathrm{a}}$

\begin{tabular}{|c|c|c|c|c|c|c|c|c|c|}
\hline \multirow[b]{2}{*}{ Mod } & & \multicolumn{2}{|c|}{$\begin{array}{l}\text { Unstandardized } \\
\text { Coef ficients }\end{array}$} & \multirow{2}{*}{$\begin{array}{c}\begin{array}{c}\text { Standardized } \\
\text { Coef ficients }\end{array} \\
\text { Beta }\end{array}$} & \multirow[b]{2}{*}{$t$} & \multirow[b]{2}{*}{ Sig. } & \multicolumn{3}{|c|}{ Correlations } \\
\hline & & B & Std. Error & & & & Zero-order & Partial & Part \\
\hline \multirow[t]{9}{*}{1} & (Constant) & $7,930 \mathrm{E}-02$ & 1,674 & & ,047 & ,962 & & & \\
\hline & Gaji & 2,057 & , 136 & ,516 & 15,095 & ,000 & ,941 & ,845 & ,214 \\
\hline & Komisi & 1,663 & , 146 & ,394 & 11,427 & , 000 & ,919 & ,768 & 162 \\
\hline & Insentif &,- 869 & , 163 &,- 224 & $-5,322$ & ,000 & ,618 &,- 487 &,- 075 \\
\hline & Tunjangan Struktural & ,369 & , 187 &, 096 & 1,973 & ,052 & 843 & 203 & ,028 \\
\hline & Bayaran &, 581 & , 142 & , 127 & 4,104 & ,000 & ,796 & ,395 & ,058 \\
\hline & Jaminan Sosial & ,228 & , 149 & 053 & 1,531 & 129 & ,622 & , 159 & ,022 \\
\hline & Pengakuan & ,291 & ,111 & , 078 & 2,614 & 010 & ,812 & ,264 & ,037 \\
\hline & Tanggung jawab & $-2,428 \mathrm{E}-02$ & , 187 &,- 006 &,- 130 & 897 & 921 &,- 014 &,- 002 \\
\hline
\end{tabular}

a. Dependent Variable: Kinerja

Testing of the second hypothesis, partial test is done by statistical t test. Based on the results of regression processing (in the same appendix), it shows that the statistic $t$ of all types of compensation is $>$ ttable or $p$ $<0.05$. This means that all types of compensation are partially significant to the performance of the Apparatus.

3. The test results on the third hypothesis using the Coefficient determinant statistic (R2). Based on statistical results (R2), it shows as follows:

Table 4. Statistical Results of Determinant Coefficient Tests (R2)

Model Summary

\begin{tabular}{|l|c|r|r|r|r|}
\hline Model & $\mathrm{R}$ & $\mathrm{R}$ Square & $\begin{array}{c}\text { Adjusted } \\
\text { R Square }\end{array}$ & $\begin{array}{c}\text { Std. Error of } \\
\text { the Estimate }\end{array}$ & $\begin{array}{c}\text { Durbin- } \\
\text { Watson }\end{array}$ \\
\hline 1 &, $991^{\mathrm{a}}$ &, 982 &, 980 & 2,92 & 1,996 \\
\hline
\end{tabular}

a. Predictors: (Constant), Tanggung jawab, Jaminan Sosial, Bayaran, Pengakuan, Komisi, Gaji, Insentif, Tunjangan Struktural

b. Dependent Variable: Kinerja 
Tests on the third hypothesis states that the contribution of independent variables to the dependent variable is $98.0 \%$. This suggests that the free varaible greatly affects the dependent variable. While other factors that influence performance is only $0.2 \%$.

\section{INTERPRETATION}

From the test results obtained that financial compensation and nonfinancial compensation, both partially or simultaneously, affect the performance of the Civil Service Apparatus in the Environment Agency of Bondowoso. The following is an explanation on each research variable.

\section{Influence of Basic Salary on ASN Performance}

From the results of research on basic salary in Environmental Agency of Bondowoso, what is felt by the Apparatus is in accordance with the standard of Apparatus competence. However, the standard of basic salary received by the apparatus is still not able to meet the needs of the Apparatus or in other words the level of conformity of the basic salary received by the State Civil Apparatus in the Environment Agency of Bondowoso at this time is still not in accordance with the standard of competence ability Apparatus or respondents. Thus, the standard of basic salary is still not appropriate and a new policy or to review the Government Regulation on the basic salary is necessarily needed.

This research is in line with research conducted by Long (2008) and Harahap (2013) which states that employee performance is influenced by the compensation and basic salary given to employees.

\section{The Commission's Influence on ASN Performance}

From the results of the research, it is found that in general the Apparatus understands the meaning and basic of compensation for the apparatus. And the level of compliance with the compensation felt by the Apparatus has been in accordance with the duties and responsibilities. Thus, the development of human resources within the Environment Agency of Bondowoso has considered many aspects and has rewarded the contribution of the Apparatus to the organization.

So it is clear that compensation in accordance with the needs will be able to contribute the improvement of the performance of the Apparatus if it covers some of the above. In the present circumstances, the provision of compensation has been deemed to attain aspects of the basic aspects of compensation. Where based on the percentage of compensation development, compensation itself becomes the fifth choice from the development of compensation as needed and able to improve the performance of the Civil State Apparatus in the Environment Agency of Bondowoso.

\section{Influence of Incentive on ASN Performance}

From the results of research and data analysis data, incentives is the second choice after the basic salary in the level of its contribution to the improvement of apparatus performance in Environment Agency of Bondowoso. Two key points to remember in delivering the incentive program for the Apparatus are: First, the apparatus must understand the basic scope and restrictions that apply to the incentive program for the Apparatus. Second, the Apparatus must be personally guided to recognize their incentive system on a periodic basis. In addition, there needs to be a strategic consideration in designing incentive programs, with long-term strategic business plan, apparatus 
characteristics, incentive competitiveness offered and overall incentive system strategy. The development of incentive compensation is the third most expected choice by the Apparatus in the Environment Agency of Bondowoso.

This research is in line with research conducted by Long (2008) and Harahap (2013) which states that the performance of employees is influenced by the incentive system provided to employees.

\section{Effect of structural Allowance on ASN Performance}

From the results of the study by conducting a review of the achievement of the mean value, then the structural allowance is the second choice after the basic salary in the development of the most appropriate compensation and the most expected and which is able to contribute to improve the performance of Apparatus in the environment.

This research is in line with research conducted by Long (2008) and Harahap (2013) which states that employee performance is influenced by the structural allowance given to employees.

\section{The effect of overtime pay on ASN Performance}

From the results of research and data analysis that has been done previously, it was obtained a result that payments in the development of compensation occupy the fourth level of the most expected and able to contribute to improve the performance Apparatus. So the pay in compensation development is still better or most expected by the Apparatus rather than social security.

From the results of other data analysis, it was found that the apparatus felt it was necessary to get paid for certain tasks or work outside of hours worked that has been completed. And the Apparatus is in agreement with the current system of payments, although there is still a need for a change or review of the paying base at this time.

\section{The Effect of Social Security on ASN Performance}

From the research result, it is found that social security is the sixth choice about the compensation expected by the Apparatus. Despite the fact that social benefits have substantial benefits for the Apparatus and their families. Like incentives, the Apparatus got poorly understand about the basis of the determination of social security, so they thought it is essentially needed for explanation or information on the basis of the provision of social security. In addition, in fact it needs to be a basic change in the provision of social security, so the Apparatus feel that social benefits will be more useful for them.

This study is in line with research conducted by Harahap (2013) which states that the performance of employees is influenced by the provision of security guarantees received by employees

\section{The Influence of Acknowledgment on ASN Performance}

From the results of other data analysis, it was found that the Apparatus felt it was necessary to get the recognition of certain tasks or tasks outside working hours that have been completed. And the Apparatus were in agreement with the current system of recognition. However, there is still a need for a change or reinstatement of the services of recognition given by superiors to subordinates that exist today because the recognition is limited to certain people who are considered capable by superiors while the standard criteria for the ability of an Apparatus can not be established.

This study is in line with research conducted by Long (2008) and Bey (2008) which states that employee performance is 
influenced by motivation and recognition of the work done.

\section{Effect of Responsibility on ASN Performance}

Giving authority to run a type of work or task by superiors sometimes can be done by the whole subordinate. Apparatus can be motivated by giving greater responsibility for his work. This is a very essential process of empowerment. The giving of responsibilities is in line with the concept of intrinsic motivation based on the content of office. It is also related to the fundamental concept that individuals are motivated when they are given the means to attain their goals. The process of distributing out the task is one of the process of giving responsibility. This can avoid a culture attached to a Civilian Personnel who has always highlighted that the State Civil Apparatus has very low performance and discipline.

This study is in line with research conducted by Long (2008) and Bey (2008) which states that employee performance is influenced by motivation, responsibility and acknowledgment of work performed.

\section{CONCLUSION}

Compensation consist of basic salary, commission, incentive, structural allowance, overtime pay, social security, recognition and responsibility both partially and collectively affect performance. The contribution of variable compensation to performance is very dominant. This is shown by the coefficient of determination of $0.98 \%$.

\section{IMPLICATIONS}

The results of this study can be used as the basis of policy making efforts of performance improvement that needs to be evaluated on the basis of providing compensation to the Environmental Agency of Bondowoso Regency in accordance with the needs and workloads undertake. This study is in accordance with the theoretical foundation that compensate the performance of employees.

\section{REFERENCES}

As'ad. Muh., 2012, Seri Ilmu Sumber Daya Manusia "Psikologi Industri", Liberty, Yogyakarta.

Azwar, Saifuddin, 2013., Penyusunan Skala Psikologi. Penerbit Pustaka Pelajar. Yogyakarta.

Azwar, Saifuddin, 2013, Reliabilitas dan Validitas, Penerbit Pustaka Pelajar, Yoo, akarta.

Dessler, G., 2008, Manajemen Sumber Daya Manusia, Alih Bahasa Benyamin Molan, PT. Prenhallindo, Jakarta.

Dharma, Agus; 2010, Manajemen Prestasi Kerja, Edisi Ketiga, Rajawali, Jakarta.

Endah Setvowati, 2007. Pengaruh komitmen Pegawai Negeri Sipil Terhadap Kinerja Pegawai Negeri Sipil pada Pemerintah Kabupaten Malang, Universitas Brawijaya Malang.

Faisal, Sanapiah., 2009., Metodologi Penelitian Diskriptif, Penerbit Erlangga, Jakarta.

Hadi, Sutrisno, 2008, Metodologi Penelitian, BPFE, UGM, Yo-yakarta. Jakarta.

Long, RJ, 2008, Compensation in Canada, International Thomso Publishing, Canada.

Long, RJ., 2000, Management by System; Mc Graw Hill Book Company Inc. New York.

Mangkunegoro, Anwar Prabu, 2012, Manajemen Sumber Daya Manusia Perusahaan, Cet. Keempat, PT. Remaja Rosdakarya Bandung.

McClelland, David C.. \&- Winter, D.G., 2007. Motivation Economic Achievement. The Free Press : New York, 
Moekijat, 2009, Manajemen Kepegawaian, Penerbit Alumni, Bandung

Nainggolan, 2003, Pembinaan Pegawai Negeri Sipil. Penerbit Haji Masagung

Nasir, Muh., 2005, Metodologi Penelitian, Ghalia Indonesia, Cetakan kelima, Jakarta.

Negara (ASN)

Pahlawarisjah Harahap, 2013,

Pengembangan Karier Sumber Daya Manusia di Perguruan Tinggi Swasta (suatu studi tentang aspek motivasi, status dan prestasi kerja dosen perguruan tinggi swasta di Kopertis VI Jawa Tengah), Untag Surabaya.

Reksohadiprojo, Sukarmo \& T. Hani Handoko, 2002, Organisasi Perusahaan Teori Struktur dan Perilaku, BPFE Yogyakarta.

Sikula, A.E., $\quad 2001, \quad$ Personnel Administration and Human Resources Management, John Wiley \& Sons, Inc.

Simamora, Henry, 2007, Manajemen Sumber Daya Manusia, Edisi Kelima, STIE YKPN, Yogyakarta, hal. 541

Singarimbun, Masri dan Sofyan., 2009, Metode Penelitian Diskriptif, LP3ES, Jakarta.

Singarimbun, Masri., 2009, Metode Penelitian Survey "Metode dan Proses Penelitian, diedit oleh Masri Singarimbun \& Sofyan
Effendy, LP3ES, Jakarta.

Soenarjo, 2009, Suatu studi kebijakan tentang kematangan pekerjaan dan kematangan kejiwaan aparatur di Sekretariat Wilayah/Daerah Kabupaten Jombang, Universitas Brawijaya Malang.

Sri Suryani, 2007, Pengaruh Gaya Kepemimpinan Situasional terhadap Prestasi Kerja pada PT. Perkebunan Nusantara XII, Universitas Brawijava Malang

Steers, Richard M. \& Spencer, D.G., 2008, The Role of Abievement Motivation in Job Design. Journal of Applied Psychology.

Sudomo, 2006, Meningkatkan Kualitas dan Investasi Sumber Daya Manusia, No. 11, Prisma, Jakarta.

Sukarno, Edy, 2012, Sistem Pengendalian Manajemen "Suatu Pendekatan Praktis", PT. Gramedia Pustaka Utama, Jakarta.I

Sunarto, 2014, Manajemen Imbalan, Amus, Yogyakarta.

Thamrin Bey, 2008, Pengaruh Total Quality Control dan Motivasi KerjaBagi Karyawan Pegawai Negeri Sipil di lingkungan Sekretariat Daerah Propinsi Jawa Timur, Universitas Airlangga.

Thamrin Bey, 2008, Total Quality Control Undang-Undang Republik Indonesia Nomor 5 Tahun 2014 tentang Aparatur Sipil

\section{BIOGRAPHY}

Suharto was born in Bondowoso on January 15, 1967. The author has a wife with two children and currently lives in Bondowoso. His last education is Master Program of Management of STIE Mandala graduated in July 2017. His writing concern is the issue of Human Resource Management. He currently serves as Head of Taman Krocok of Bondowoso Regency. 